Reprod. Nutr. Dévelop., 1982, 22 (1 B), 153-162.

\title{
Migration and differentiation of neural crest cells and their derivatives : in vivo and in vitro studies on the early development of the avian peripheral nervous system
}

\author{
Catherine ZILLER, J. SMITH
}

\begin{abstract}
Institut d'Embryologie du CNRS et du Collège de France, 49 bis, avenue de la Belle-Gabrielle, 94130 Nogent-sur-Marne, France.
\end{abstract}

Summary. After a period of extensive migration through the vertebrate embryo, neural crest cells differentiate into a great variety of cell types, including all the elements of the peripheral nervous system. We have studied crest cell migration in quail-chick chimeras in which quail cells can be identified by means of a stable natural nuclear marker. The results of interspecific grafts of neural primordium, performed systematically at different levels of the neuraxis, have established the sites of origin of the principal peripheral ganglia. In addition, they suggest that the cholinergic and adrenergic phenotypes are not predetermined in the neural crest before migration, but are the result of multiple cellular interactions. Furthermore, the phenotype expression of young differentiating autonomic ganglia is labile and can be modified if the latter are subjected to an appropriate cellular environment by grafting into a younger host embryo. The results of experiments in which fragments of neural crest, sensory and autonomic ganglia were transplanted are presented in terms of a model of crest cell-line segregation.

As a step towards the analysis of the cellular interactions occurring during autonomic neuron differentiation, we have also studied neuronal development in tissue cultures of neural crest, taken from the cranial and trunk levels of quail embryos and grown in the presence or absence of other embryonic tissues. The results confirm that both levels of the crest are potentially able to give rise to cells that can make acetylcholine and catecholamines. However, whereas acetylcholine-synthesizing ability is apparently a very early feature of autonomic neuron precursors, the ability to produce catecholamines is acquired later as a result of interactions with other cell types, in particular with mesenchymal derivatives. Although production of both neurotransmitters can be considerably stimulated by associating crest with any of several young embryonic rudiments, only when trunk crest is cultured with the sclerotomal moiety of the somite is biochemical differentiation accompanied by extensive morphological and cytochemical neuronal maturation.

Because of the extensive migrations accomplished by neural crest cells in early vertebrate development and because of the great variety of differentiated cell types derived from the neural crest, this system is very suitable for the study both of cell movements during embryonic life and of problems of cell differentiation. 
In particular, the development of the peripheral nervous system (PNS) has been studied intensively during the last few years. It is well known that all the ganglion cells and supporting cells of the PNS derive from the neural crest (Horstadius, 1950 ; Weston, 1970) ; so, an apparently homogeneous, undifferentiated cell population gives rise to spinal ganglion cells, adrenergic sympathetic neurons and adrenomedullary cells, and to cholinergic parasympathetic plexuses and ganglia.

The neural crest is located along the margin of the neural primordium at the neurula stage. During the closure of the neural tube, the crest cells leave their site of origin and undergo migration in the developing organism, eventually localizing in various environments and differentiating to form the ganglia of the PNS and many other cell types (melanocytes, endocrine cells, mesenchymal tissues).

How do the seemingly identical crest cells choose their migration pathway, site of arrest and phenotype ? If we consider in particular the development of the autonomic nervous system (ANS), how do they decide which neurotransmitter to produce acetylcholine (ACh) for the parasympathetic cholinergic cells or noradrenaline for the sympathetic adrenergic cells ?

Several experimental approaches have been used to try and find an answer to these questions. This review is a summary of the results obtained in this field by different workers and especially in our laboratory.

\section{Origin of peripheral ganglia in the neural crest}

Suitable marking techniques have allowed the migration of neural crest cells from different levels of the cephalocaudal neural axis to be followed. Thus a fate map of the neural crest, especially in respect to the PNS, has been established. The first method used was the implantation of ${ }^{3} \mathrm{H}$-thymidine-labelled neural crest grafts into an unlabelled host (Weston, 1963 ; Chibon, 1966), followed by histoautoradiography. However, the isotopic label was not stable, because the radioactivity in the nuclei was diluted due to rapid cell multiplication in the developing embryo. Thus, only the early migration of crest cells could be studied. A more precise knowledge of neural crest cell migration and of its final fate has been obtained thanks to the stable marking technique devised by Le Douarin (1969). This method is based on the fact that the cell nuclei of two species of birds, the quail and the chick, have different structures which can be easily evidenced by a specific staining of the DNA (Feulgen-Rossenbeck). The early stages of quail and chick embryonic development being very similar and transplantation between the two species easy and successful, chimeric embryos can be constructed which develop and hatch normally.

Interspecific isotopic transplantations of fragments of the neural primordium, performed systematically along the neural axis at the neurula stage (2-day-chick and quail), were followed by histological examination of the chimeras obtained, thus permitting the precise origin of every neural crest derivative to be established 
(Le Douarin and Teillet, 1973 ; Teillet, 1978). The fate map obtained for the PNS is the following :

- the mesencephalic neural crest gives rise to the ciliary ganglion (autonomic, parasympathetic, cholinergic) (Narayanan and Narayanan, 1978) ;

- the neural crest of the vagal region, corresponding to the level of somites 1 to 7 , produces the enteric plexuses and ganglia of the digestive tract: Meissner's and Auerbach's plexuses (autonomic, parasympathetic, cholinergic) :

- from the level of the sixth somite caudad, the entire length of the neural crest gives rise to the orthosympathetic chain (adrenergic ganglia) ;

- the adrenomedulla derives from the neural crest located at the level of somites $18-24$;

- the lumbo-sacral region of the crest, posterior to somite 18, gives rise to the parasympathetic ganglion of Remak; it also contributes to the plexuses of Meissner and Auerbach of the postumbilical gut ;

- at the level of each somite, the spinal ganglia derive from the corresponding region of the crest.

It appears from these results that the neural crest is regionalized before its cells start to migrate. Each cephalocaudal level of the crest gives rise to a specific part of the PNS. For example, if we consider its contribution to the neurons of the ANS, the neural crest extending from the level of the 7th somite to the level of the 28th somite produces only adrenergic cells, i.e. neurons of the sympathetic chain and aortic plexus, and adrenomedullary cells; it does not participate in the parasympathetic innervation of the gut. The cephalic and the vagal crest (somites 1-5) produce only parasympathetic cholinergic derivatives.

\section{Plasticity of neural crest-derived cells}

a) Although seemingly homogeneous, the crest cell population appears to be heterogeneous with respect to its potentialities to differentiate into sympathetic and parasympathetic ganglia, in other words to synthesize catecholamines (CA) or ACh as neurotransmitters. Is this early determination a stable one or can the fate of neural crest cells be changed by artificially altering their initial localization along the axis of the embryo? To answer these questions, heterotopic transplantations of neural primordia were performed between quail and chick embryos (Le Douarin and Teillet, 1974). For example, in a chick host, the neural primordium of the adrenomedullary level (somites 18-24), which normally produces only adrenergic cells, was replaced by an equivalent length of a quail neural primordium, excised from the vagal level (somites 1-5), which normally produces cholinergic cells. Histological examination of the chimera obtained showed that the sympathetic ganglia, aortic plexus and adrenal glands in the grafted region of the host were colonized by numerous quail cells which had become adrenergic, as evidenced by formaldehyde-induced fluorescence (FIF) (Falck, 1962). This demonstrates that presumptive cholinergic crest cells may change their metabolic pathway, if their environment is experimentally changed. The reverse situation 
has been observed: presumptive adrenergic crest cells from a quail donor (Le Douarin et al., 1975), taken at the trunk level and grafted (Smith et al., 1977) at the vagal presumptive cholinergic region-level of a chick host, invaded the gut and formed quite normal enteric ganglia and plexuses which appeared to be cholinergic, as shown by the presence of choline acetyltransferase and acetyl cholinesterase, the enzymes of $\mathrm{ACh}$ synthesis and degradation.

The conclusion from this series of heterotopic transplantations is that the determination of neural crest cells is labile : the migratory routes as well as the metabolic pathways of these cells depend on the environment in which the cells are placed (e.g. trunk tissues or gut) and not on their truncal or vagal origin.

b) The very important role of local environment in the determination of neural crest-derived cells is even more evident in the following series of experiments. This time, instead of exchanging the neural primordia before the onset of migration and differentiation of neural crest cells, we back-transplanted into a 2-day chick host crest derivatives, such as the ganglion of Remak, the ciliary ganglion, sympathetic ganglia or spinal ganglion, which had already achieved normal migration and were in the process of differentiation. These derivatives were taken from 4- to 6-day quail embryos at a stage when the ganglion cells already express their typical phenotype (for instance, the presence of CA or $A C h)$. The graft was inserted into the trunk region between the neural tube and the somites, close to the host's own neural crest. Thus, differentiating crestderived ganglia were subjected to the environment of the trunk of a younger embryo at the stage of neural crest cell migration and differentiation. The evolution of these supernumerary grafts was observed subsequently at various times after transplantation (Le Douarin et al., 1978 ; Le Lièvre et al., 1980). Three main results were obtained :

1) During the first hours after implantation, cells from the periphery of the grafted ganglion detached from the implant and started to migrate along the side of the host's neural tube; after 24 to $48 \mathrm{hrs,} \mathrm{the} \mathrm{cells} \mathrm{of} \mathrm{the} \mathrm{graft} \mathrm{were}$ completely dispersed among the host's truncal tissues. If examined 4 to 6 days after grafting, the chimeric embryos showed that grafted quail cells were located exclusively in the normal sites of arrest of neural crest cells, i.e. ganglia of the PNS, nerves, adrenal gland and plexuses. This means that, although at the time of transplantation the ganglion cells had already undergone migration, they behaved exactly as premigratory undifferentiated neural crest cells when placed in the neural crest environment of the host, i.e. they migrated and recognized the normal sites of arrest of neural crest cells.

2) Not only did the grafted ganglion cells locate at the normal sites of peripheral ganglion formation, but they also differentiated and expressed the phenotype corresponding to their environment; quail ciliary ganglion cells originating from a cholinergic population, or sensory ganglion cells, when found in sympathetic ganglia or adrenomedulla of the host, responded positively to FIF, indicating that they contained CA and had become adrenergic.

3) Spinal and autonomic grafted ganglia behaved differently in the host. Whereas the sensory ganglion-derived cells colonized not only the host's dorsal- 
root ganglia but also the sympathetic chain and adrenomedulla, the autonomic ganglion cells were located in the autonomic structures of the host only. This result suggests that sensory and autonomic ganglion cells have different affinities for the neural crest cell-arrest sites. We propose a model for cell line segregation during formation of neural crest derivatives : precursor cells of the PNS have to make a series of binary choices, some of which appear to be reversible. For instance, spinal ganglion cells can switch from sensory to autonomic when they are back-transplanted. Other choices, however, are irreversible ; autonomic cells, in our experiments, could not participate in the formation of the spinal ganglion (Le Lièvre et al., 1980 ; Le Douarin et al., 1981) (see table 1).

\section{TABLE 1}

Segregation of cell lines in the peripheral nervous system, as a result of a succession of binary choices. Some choices are irreversible, i.e. autonomic determination, whereas others are reversible for a while (sensory determination, or adrenergic versus cholinergic determination).

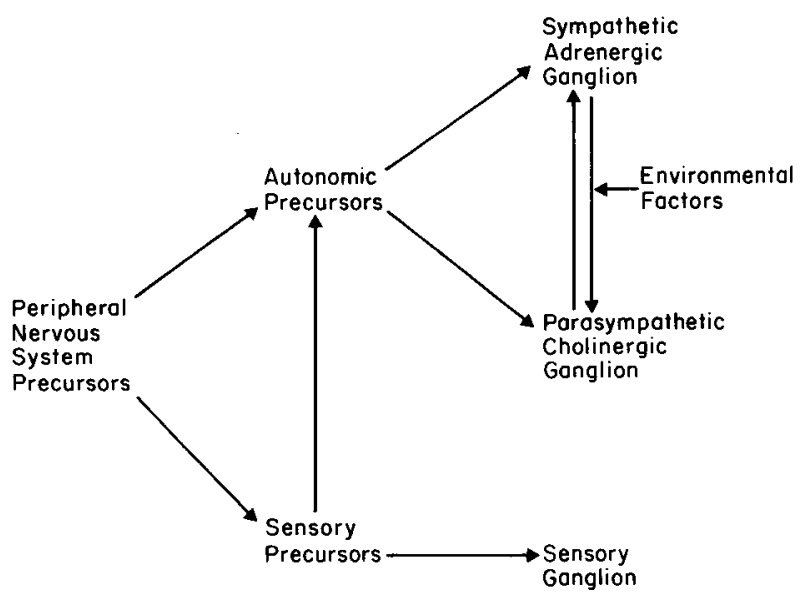

\section{Neuronal differentiation in neural crest cell cultures in vitro : biochemical and structural studies}

One of the conclusions drawn from the results described above is that the potential to give rise to cholinergic and adrenergic neurons is a feature of crest cells throughout most of the embryonic neural axis, even though a particular region may produce only one type of neuron in the normal course of events. This phenotypic selection is the result of interactions with tissues encountered by the crest cells along their migratory route and/or at their final sites of arrest and aggregation. Experimental tissue association in ovo or in organ culture have shown that neural tube, somitic mesenchyme and notochord are all implicated in the acquisition of the adrenergic phenotype (Cohen, 1972 ; Norr, 1973 ; Teillet et al., 1978). On the other hand, neural crest cells can differentiate directly into 
cholinergic neurons in the splanchnic mesenchyme in the absence of the axial embryonic structures (Smith et al., 1977). Although this type of experiment is useful in identifying tissues that affect neuronal differentiation, further analysis of the nature and mode of action of putative neurogenic factors requires an in vitro approach.

It was shown some years ago that neuronal phenotypes appeared in cultures of avian neural crest; cholinergic and adrenergic cells developed in vitro from explanted cranial and trunk neural crest, respectively (Greenberg and Schrier, 1977 ; Cohen, 1977). Several questions remained unanswered, however. Could the neural tube, present during the first two days of culture, be responsible for the apparently spontaneous adrenergic differentiation observed ? Could both levels of the crest give rise in vitro both to cholinergic and adrenergic cells ? What would be the effect of associating neural crest in vivo with the embryonic tissues involved in the development of neurotransmitter-related properties ? Our attempts to reply to these questions, reported in greater detail elsewhere (Fauquet et al., 1981), are reviewed below.

\section{a) Neurotransmitter synthesis in tissue cultures of neural crest alone.}

Crest explants were taken from either the cranial (" migrating " mesencephalic crest) or thoracic (trunk neural folds) levels of quail embryos by surgical excision ; consequently, the neural tube was not present in the cultures at any time. The cells were grown in liquid medium (DMEM supplemented with 15 p. 100 horse serum or foetal calf serum and 2 p. 100 chick embryo extract) and were examined at intervals for morphological and cytological signs of neuronal differentiation. After 7 days in vitro, the cultures were routinely tested for their ability to convert ${ }^{3} \mathrm{H}$-tyrosine and ${ }^{3} \mathrm{H}$-choline into $\mathrm{CA}$ and $\mathrm{ACh}$, respectively. This highly sensitive technique, which allows $C A$ and $A C h$ synthesis to be determined in a single sample, is a convenient way of evaluating the relative extent of adrenergic and cholinergic development in different types of cultures (Mains and Patterson, 1973 a, b).

Morphological differentiation in the cultures depended largely on the level of origin of the crest and the nature of the serum added. However, few cells with a typical neuronal morphology were visible by phase-contrast microscopy and no silver-staining or FIF-positive cells were observed. Despite this apparent lack of extensive neuronal differentiation, all the cultures examined synthesized $\mathrm{ACh}$, irrespective of the origin of the crest or the serum. However, mesencephalic crest produced significantly higher amounts in the presence of horse serum. The invariable existence of cholinergic properties in cultures of both types of crest, even after short periods in vitro, prompted us to examine the possible presence of ACh-synthesizing activity in crest before culture. We were able to show that " migrating" mesencephalic crest (free of neural tube or underlying mesenchyme) could already convert choline to ACh immediately after excision from the embryo (Smith et al., 1979). Mesencephalic crest cells thus do not acquire cholinergic properties in vitro, although their synthetic activity increases some 10-15 fold during the first week in culture. 
In contrast, not only could no CA synthesis be detected in crest before explantation, but even after 7 days in vitro, the amounts produced were extremely small in mesencephalic crest cultures and negligeable in trunk crest. CA production by the latter was increased when the neural tube was added during the early stages of culture, but the quantities of transmitter produced remained extremely low.

b) Stimulation of neurotransmitter synthesis in cultures of neural crest by association with diverse young embryonic tissues.

Our next aim was to examine the effects on neural development of coculturing neural crest with various tissues of non-crest origin. Our choice of hind-gut mesenchyme and somites-plus-notochord was determined by their effects in ovo, as mentioned above. In addition we studied the influence of embryonic heart, which is a normal target organ for both parasympathetic and sympathetic nerves. Neural crest was added to already established cultures of each of these tissues which had been removed from the embryo at a stage when they were still aneural ( 2 days for the somites and heart, 4 days for the hind-gut).

One week later, neurotransmitter synthesis was measured as before. In general, all three tissues stimulated the synthesis of both ACh and CA to a greater or lesser degree, although their effects were sometimes dependent both on the axial origin of the crest and on the type of serum present. Interestingly, trunk crest synthesized significant amounts of CA in the presence of the nonneuronal tissues, and particularly in cocultures with 2-day somites and notochord. However, despite the increased biochemical differentiation compared to cultures of crest alone, morphological neuronal development was not notably modified ; once again, few characteristic nerve cells were visible and none of the cultures examined were FIF-positive.

\section{c) Adrenergic differentiation in "migrating" trunk crest: culture of sclerotomal rudiments.}

In the quail embryo in vivo, CA fluorescence can first be observed towards the end of the 4th day of incubation in sympathoblasts that have migrated dorsolateral to the aorta and aggregated to form the primary sympathetic chains. The somitic mesenchyme itself has undergone developmental changes at this stage, and it is specifically within the sclerotomal component that the adrenergic differentiation of the neural crest derivatives occurs. The relatively poor sympathoblast differentiation occurring in mixed cultures of trunk neural fold and 2-day somitic mesenchyme incited us to study the appearance of adrenergic cells in cultured sclerotomal tissue. Sclerotomes dissociated from 3-day embryos (Cheney and Lash, 1981) contain crest-derived cells that have not yet reached their site of arrest and can thus be considered as a preparation of migrating trunk crest cells, intimately associated with the tissue into which they normally migrate and differentiate. However, at this stage no FIF-positive cells can be seen nor do isolated sclerotomes convert ${ }^{3} \mathrm{H}$-tyrosine to $\mathrm{CA}$.

Once in culture, however, the structural and biochemical differentiation of catecholaminergic neurons is very rapid, and by 5-7 days the cultures had 
produced many neurons whose processes, often forming an extensive network, were sometimes grouped to form ganglion-like structures. Such cells were acetylcholinesterase-positive and stained with silver and methylene blue. The first fluorescent cells appeared within $48 \mathrm{hrs}$, and 3-4 days later large numbers of neurons, processes and varicosities were strongly positive. Electron microscopic examination revealed numerous dense-core vesicles of diverse sizes.

Unlike CA, ACh was produced by sclerotomes prior to explantation. However, both $\mathrm{CA}$ and $\mathrm{ACh}$ were synthesized in all cultures examined from $24 \mathrm{hrs}$ onward ; in contrast to the results obtained with excised neural crest grown alone or in association with 2-day somites or heart, the molar ratio, which was in favour of CA at all times, was similar to that characteristic of cultured sympathetic ganglia.

In conclusion, these experiments confirm that both cranial and cervicothoracic crest have the potential to produce both cholinergic and adrenergic cells. Similar bipotentiality of neural crest in vitro has recently been described (Kahn et al., 1980). However, our results reveal what appears to be a fundamental difference between cholinergic and adrenergic differentiation. Whereas the former already exists in cells that are migrating at the cephalic level and probably also at the trunk level (as ACh synthesis by freshly-dissociated sclerotomes would suggest), CA synthesis occurs later and, at least under our experimental conditions, apparently requires interactions between crest cells and mesenchyme derivatives.

As far as cholinergic development is concerned, the effect of target tissues would thus be to amplify the basal level of cholinergic activity. Stimulation of cholinergic differentiation in neural crest associated with gut, somite or heart is consistent with this view and may well be related to the fact that muscle (all three embryonic tissues have muscular components) contains soluble factors increasing CAT activity in cultures of various types of central and peripheral neurons (Giller et al., 1973 ; Godfrey et al., 1980 ; McLennan and Hendry, 1980).

Although a variety of tissues could initiate adrenergic differentiation in crestderived cells (reflected by the conversion of ${ }^{3} \mathrm{H}$-tyrosine to $\mathrm{CA}$ at low levels), consolidation of the phenotype (increased CA synthetic activity, presence of CA stores and associated cytological properties) only occurs within the sclerotomal environment. Whether this result reflects a specific " adrenergizing " influence inherent to the sclerotome or an increased maturity of the migrating trunk crest cells within it at the moment of explantation, remains to be determined.

7e Réunion du groupe Développement I.N.R.A., Nouzilly/Tours, 14-15 mai 1981.

Résumé. Tous les éléments du système nerveux périphérique des Vertébrés sont issus de la crête neurale, ébauche située chez la neurula sur les bords des replis neuraux. Lors de la fermeture du tube nerveux, les cellules de la crête neurale quittent leur site d'origine et entreprennent des migrations étendues, au terme desquelles elles se différencient, donnant naissance, en des localisations diverses, à de nombreux dérivés, en particulier aux ganglions du système nerveux périphérique. Ces migrations ont été suivies chez des embryons 
chimères de caille et de poulet grâce à un marquage basé sur les différences de structure des noyaux cellulaires de ces deux espèces. Des greffes interspécifiques d'ébauches neurales effectuées systématiquement tout le long de l'axe nerveux ont permis 1) d'établir le lieu d'origine des principaux dérivés ganglionnaires périphériques, en particulier sympathiques et parasympathiques ; 2 ) de montrer que la détermination des divers types cellulaires, entre autres des phénotypes sympathique adrénergique et parasympathique cholinergique, n'est pas établie dans la crête neurale mais que leur différenciation résulte d'interactions cellulaires multiples. Des transplantations de ganglions autonomes en cours de différenciation ont montré que leur expression phénotypique est labile et peut être modifiée s'ils sont soumis à un environnement différent de celui de leur localisation normale. $D^{\prime}$ autre part, des greffes de fragments de crête neurale et de ganglions rachidiens et autonomes ont permis de suggérer un modèle de ségrégation des lignées cellulaires issues de la crête neurale.

Par ailleurs, la différenciation neuronale a été étudiée in vitro, selon des critères biochimiques et cytologiques, dans des cultures histiotypiques de crête neurale, prélevée aux niveaux cranial et troncal de l'embryon de caille et cultivée seule ou en présence d'autres tissus embryonnaires. Nous apportons la confirmation que chacun de ces niveaux de la crête peut fournir des cellules produisant de l'acétylcholine et des catécholamines. Cependant, si les précurseurs des neurones autonomes possèdent la capacité de synthétiser de l'acétylcholine dès un stade très précoce, la propriété de convertir de la tyrosine en catécholamines est acquise plus tardivement, suite à des interactions avec des dérivés mésenchymateux notamment. La production des deux transmetteurs peut être considérablement augmentée si la crête neurale est cultivée avec plusieurs tissus embryonnaires, mais seule l'association de la crête troncale et la partie sclérotomiale du somite permet à la fois une différenciation biochimique et une maturation cytochimique et morphologique importante de neurones.

\section{References}

CHENEY C.M., LASH J. W., 1981. Diversification within embryonic chick somites : differential response to notochord. Dev. Biol, 81, 288-298.

CHIBON P., 1966. Analyse expérimentale de la régionalisation et des capacités morphogénétiques de la crête neurale chez l'Amphibien Urodèle Pleurodeles waltlii (Michah). Mém. Soc. Zool. Fr., 36, 1-107.

COHEN A. M., 1972. Factors directing the expression of sympathetic nerve traits in cells of neural crest origin. J. exp. Zool., 179, 167-182.

COHEN A. M., 1977. Independent expression of the adrenergic phenotype by neural crest cells in vitro. Proc. nat. Acad. Sci. USA, 74, 2899-2903.

FALCK B., 1962. Observations on the possibilities of the cellular localization of monoamines by a fluorescence method. Acta physiol. Scand., suppl. 56, 197-354.

FAUQUET M., SMITH J., ZILLER C., LE DOUARIN N. M., 1981. Differentiation of autonomic neuron precursors in vitro : cholinergic and adrenergic traits in cultured neural crest cells. J. Neurosc., 1, 478-492.

GILLER E. L., SCHRIER B. K., SHAINBERG A., FISK H. R., NELSON P. G., 1973. Choline acetyltransferase activity is increased in combined cultures of spinal cord and muscle cells from mice. Science, 182, 588-589.

GODFREY E. W., SCHRIER B. K., NELSON P. G., 1980. Source and target cell specificities of a conditioned medium factor that increases choline acetyltransferase activity in cultured spinal cord cells. Dev. Biol., 77, 403-418.

GREENBERG J. H., SCHRIER B. K., 1977. Development of CAT activity in chick cranial neural crest cells in culture- Dev. Biol., 61, 86-93.

HORSTADIUS S., 1950. The neural crest : its properties and derivatives in the light of experimental research., Univ. Press, London, Oxford, $111 \mathrm{pp}$.

KAHN C. R., COYLE J. T., COHEN A. M., 1980. Head and trunk neural crest in vitro : autonomic neuron differentiation. Dev. Biol., 77, 340-348. 
LE DOUARIN N., 1969. Particularités du noyau interphasique chez la caille japonaise (Coturnix coturnix japonica). Utilisation de ces particularités comme " marquage biologique " dans les recherches sur les interactions tissulaires et les migrations cellulaires au cours de l'ontogenèse. Bull. Biol. Fr. Belg., 103, 435-452.

LE DouARIN N. M., RENAUD D., TElLLET M. A., LE DOUARIN G. H., 1975. Cholinergic differentiation of presumptive adrenergic neuroblasts in interspecific chimaeras after heterotopic transplantations. Proc. nat. Acad. Sci. USA, 72, 728-732.

LE DOUARIN N. M., SMITH J., LE LIEVRE C. S., 1981. From the neural crest to the ganglia of the peripheral nervous system. Annu. Rev. Physiol., 43, 653-671.

LE DOUARIN N., TEILLET M. A., 1973. The migration of neural crest cells to the wall of the digestive tract in avian embryo. J. Embryol. exp. Morph., 30, 31-48.

LE DOUARIN N., TEILLET M. A., 1974. Experimental analysis of the migration and differentiation of neuroblasts of the autonomic nervous system and of neurectodermal mesenchymal derivatives, using a biological cell marking technique. Dev. Biol., 41, 162-184.

LE DOUARIN N. M., TEILLET M. A., ZILLER C., SMITH J., 1978. Adrenergic differentiation of cells of the cholinergic ciliary and Remak ganglia in avian embryo after in vivo transplantation. Proc. nat. Acad. Sci. USA, 75, 2030-2034.

LE LIĖVRE C. S., SCHWEIZER G. G., ZILLER C. M., LE DOUARIN N. M., 1980. Restrictions of developmental capabilities in neural crest cell derivatives as tested by in vivo transplantation experiments. Dev. Biol., 77, 362-378.

MCLENNAN I. S., HENDRY I. A., 1980. Influence of cardiac extracts on cultured ciliary ganglia. Dev. Neurosci., 3, 1-10.

MAINS R. E., PATTERSON P. H., 1973a. Primary cultures of dissociated sympathetic neurons. I. Establishment of long-term growth in culture and studies of differentiated properties. J. Cell Biol., 59, 329-345.

MAINS R. E., PATTERSON P. H., 1973b. Primary cultures of dissociated sympathetic neurons. III. Changes in metabolism with age in culture. J. Cell Biol., 59, 361-366.

NARAYANAN C. H., NARAYANAN Y., 1978. On the origin of the ciliary ganglion in birds studied by the method of interspecific transplantation of embryonic brain regions between quail and chick. J. Embryol. exp. Morph., 47, 137-148.

NORR S. C., 1973. In vitro analysis of sympathetic neuron differentiation from chick neural crest cells. Dev. Biol., 34, 16-38.

SMITH J., COCHARD P., LE DOUARIN N. M., 1977. Development of choline acetyltransferase and cholinesterase activities in enteric ganglia derived from presumptive adrenergic and cholinergic levels of the neural crest. Cell Diff., 6, 199-216.

SMITH J., FAUQUET M., ZILLER C., LE DOUARIN N. M., 1979. Acetylcholine synthesis by mesencephalic neural crest cells in the process of migration in vivo. Nature, 282, 852-855.

TEILLET M. A., 1978. Evolution of the Jumbo-sacral neural crest in the avian embryo : origin and differentiation of the ganglionated nerve of Remak studied in interspecific quail-chick chimaerae. Wilhelm Roux's Archiv. Dev. Biol., 184, 251-268.

TEILLET M. A., COCHARD P., LE DOUARIN N. M., 1978. Relative roles of the mesenchymal tissues and of the complex neural tube-notochord on the expression of adrenergic metabolism in neural crest cells. Zoon, 6, 115-122.

WESTON J. A., 1963. A radioautographic analysis of the migration and the localization of trunk neural crest cells in the chick. Dev. Biol., 6, 279-310.

WESTON J. A., 1970. The migration and differentiation of neural crest cells. In M. ABERCROMBIE, J. BRACHET, T. J. KING, Advances in morphogenesis, 8, 41-114, Acad. Press, New York. 